\title{
An Imperishable Education to the Present Scenario
}

\author{
Dr. S. Jayanthi
}

M.A., M.Phil., Ph.D., Assistant Professor of English, PSG College of Arts \& Science, Coimbatore 641004, Tamil Nadu, India

\begin{abstract}
Under the present-day educational system, students go to educational institution to follow a syllabus which has been set for pushing towards professional knowledge but not for wisdom to life. We want that education to built up pupil's character and it should strength of mind and inner wisdom to lead good life in this earth. All the experiences involving our interaction in society shape our mind. The teacher must throw his or her whole force into the tendency of the thought. The true teacher is one who immediately come down to the level of the student, and transfer his soul to the students' soul and seen through and understand through his mind. Such a teacher can really teach. The present research paper deals about today's education in different aspects.
\end{abstract}

Keywords: Education, Teaching, Learning, knowledge, Wisdom, etc

\section{Introduction}

In teaching we should have a positive approach, an approach which is based on the dignity of and faith in the human personality. Teacher should give positive ideas. Negative thoughts only weaken pupils. If we give them positive ideas, pupils will grow up to be a good human and learn to stand on their own legs. The most fruitful approach to life is to have faith and confidence in one's own ability and work. Let every young man and women be instilled with the great manly thought that he or she is the master of his or her destiny. Hard, intelligent, continuous and co-operative work is the gateway to all greatness. Man has received only a coating of civilization; scratch him, the barbarian comes out. Most of our morality is the policeman's morality, namely, observed not out of conviction but out of fear of the policeman, the law and the jail. In the cultivation of positive qualities, the co-operation of three agencies play a vital role, namely, the family, the school and community. The child gets his first ideas and attitudes from parents, if both mother and father stress the same qualities and kinds of behaviour; the child gets the strength to follow them without doubt or confusion. So, parents are the first teacher to the child.

\section{The Function of the Teacher}

The teacher is to be held in very high respect by his disciples. The exhortation to the outgoing students in the Taittireya Upanished Shows how the students were asked to regard the teacher as the representation of the Divine along with the mother and the father. Modern books on education describe some specific qualities that a teacher must possess to be successful in his profession. He must know his subject well, he must know how to teach effectively and he must have genuine love for his pupils. This implies that he must be learning continuously, to be up to date in his field of knowledge. Without love of learning one cannot give of his best to his pupils. In addition, a good teacher must have a good memory, personality, determination, will power, persuasive ability, tact and understanding of the ways of the young. All these have prescribed as the essential qualities of a teacher. Furthermore, it has been emphasised that the teacher must be a good example to his wards. He should live in his daily life what he preaches. Teacher has been described as leading the pupil from the darkness of ignorance to the light of learning. The teacher must knows the spirit of the scriptures. The true teaches will immediately come down to the level of the student, and transfer his soul to the student's soul and see through and understand through his mind. Our teachers should not only be intellectual giants, but spiritual lamps. Their lives should be examples of the great truths they preach.

\section{The Ideal of Education}

The ideal of education is the development of the personality of the student through the development of his character. Born with ordinary capacities they developed their talents to great dimensions through effort and concentration. No great achievement will ever be possible without the concentration of mind and effort. By constant practice, they trained their minds for greater achievements. A great deal has been written on methods of teaching in our schools and colleges. The activity method, the project method, individual attention, relating teaching to pupils' experiences, use of audio-visual aids such as the cinema, drama, radio and television and a variety of similar devices have been recommended by eminent teachers and academicians. The basic objective of using all these methods is to create interest in the pupil, so that he is able to concentrate his mind on the subject of his study. There is only one method by which to attain knowledge, that which is called concentration. The very essence of education is concentration of mind. The more the power of concentration, the greater the knowledge that is acquired. Concentration of mind is the secret of the source of power of the scientists who probe the external world and of the prophets who probe the inner world of the spirit.

The educated man is expected to have a thinking mind. He must be able to relate the knowledge which he has gained from his books to his work. The knowledge of many educated men however is fragmentary which they are not able to relate to their work. One might have studied higher mathematics, but is not able to apply it to the building of one's own house. Such knowledge does not make a person truly educated. Education thus is the process by which man acquires the ability to think. But unfortunately in the modern age when knowledge has widened its frontiers, education has come to mean amassing of information and facts, to the detriment of the power to think. Learning to think is not a matter only of intellectual practice, it is also one of moral 


\section{International Journal of Science and Research (IJSR) \\ ISSN (Online): 2319-7064}

Index Copernicus Value (2016): 79.57 | Impact Factor (2015): 6.391

conviction and courage to stand by and follow it at all risks. Our education, if it is to be real, should infuse in our young men and women the courage to think independently, understand clearly, and act courageously. The greatness of the educational system of any country will be measured by the number of such thinking men and women it produces.

A steady mind is absolutely necessary for progress and success in life our heart is like a mirror as long as it is covered with the dust of impurity, it cannot reflect the true self. Hence purification of the heart is most essential for wisdom attainment. It can be done by good education. The knowledge imparted should be functional and calculated to improve the lives of the people. The mind is everything. If the mind loses its positive thinking it lose everything. Education is not the amount of information that is put into our brain and runs riot there, undigested all our life. The end of all education all training, should be man making. The end and aim of all training is to make the man grow. The training by which the current and expression of will are brought under control and become fruitful is called education.

\section{Learning to Think}

The educated man is expected to have a thinking mind. He must be able to relate the knowledge which he has gained from his books to his work. The knowledge of many educated men however is fragmentary which they are not able to relate to their work. He might have studied higher mathematics, but is not able to apply it to the building of his own house. Such knowledge does not make a person truly educated. Education thus is the process by which man acquires the ability to think. But unfortunately in the modern age when knowledge has widened its frontiers, education has come to mean amassing of information and facts, to the detriment of the power to think. Learning to think is not a matter only of intellectual practice, it is also one of moral conviction and courage to stand by and follow it at all risk. Our education, of it is to be real, should infuse in our young men and women the courage to think independently, understand clearly, and act courageously. The greatness of the educational system of any country will be measured by the number of such thinking men and women it produces.

\section{Conclusion}

The educational system must make its contribution to the development of habits, attitudes and qualities of democratic citizenship to counteract the fissiparous tendencies which tend to divide the country. Citizenship in a democracy involves the cultivation of many intellectual, social and moral qualities. A nation is advanced in proportion as education and intelligence spread among the masses. Teach the masses in the vernaculars. Give them ideas; they will get information, but something more will be necessary. Give them culture. The ideal of all education, all training, should be this man making. But, instead of that, we are always trying to polish up the outside. The end and aim of all training is to make the man grow. The training by which the current and expression of will are brought under control and become fruitful, is called education.

\section{References}

[1] Seidman, R.H., \& Painchaud, S.R. (2012). Saving higher education: the integrated, competency-based three-year bachelor's degree program. San Francisco: Jossey-Bass.

[2] Webster, F. (1995) Theories of the Information Society. Routledge (third edition, 2006).

[3] Seidman, R.H., \& Painchaud, S.R. (2012). Saving higher education: the integrated, competency-based three-year bachelor's degree program. San Francisco: Jossey-Bass.

[4] http://mgcgvchitrakoot.academia.edu/keshavpatel

[5] https://www.scribd.com/document/52399813/VIVEKA NANDA-On-Mass-Education

[6] http://www.vivekananda.net/Quotations/A-F.html

Volume 6 Issue 12, December 2017 www.ijsr.net 